\title{
Polimorfisme Protein Plasma Darah pada Kelinci Rex, Lokal dan New Zealand White
}

\author{
(POLYMORPHISM OF BLOOD PLASMA PROTEIN \\ OF REX, LOCAL AND NEW ZEALAND WHITE RABBIT) \\ Riri Sarfan ${ }^{1}$, Sutopo $^{2}$ Edy Kurnianto ${ }^{2}$ \\ ${ }^{1}$ Mahasiswa Magister Ilmu Ternak, \\ ${ }^{2}$ Laboratorium Genetika, Pemuliaan, dan Reproduksi, \\ Fakultas Peternakan dan Pertanian, Universitas Diponegoro \\ Jl. Prof. Soedarto SH, Tembalang, Kota Semarang, \\ Jawa Tengah, Indonesia 50275 \\ E-mail: kurniantoedy17@gmail.com: Telp 08164250722
}

\begin{abstract}
ABSTRAK
Tujuan penelitian ini adalah untuk mengetahui keragaman genetik kelinci melalui analisis keragaman protein plasma darah dengan metode elektroforesis pada lokus pre-albumin $(P a)$, albumin $(A l b)$, ceruloplasmin $(C p)$, transferin $(T f)$, post-transferin $(P$ - $t f)$, dan amylase-I $(A m-I)$. Analisis darah dilakukan di Laboratorium Fisiologi dan Biokimia, Fakultas Kedokteran Hewan, Universitas Gadjah Mada, Yogyakarta. Sebanyak 63 sampel darah kelinci rex, lokal dan New Zealand White (NZW) masing-masing sebanyak 21 sampel digunakan dalam penelitian ini. Penentuan kelinci dilakukan dengan metode observasional dengan cara kelinci dipilih secara acak. Pita-pita protein yang dihasilkan dari elektroforesis digunakan untuk menghitung nilai frekuensi gen. Perhitungan nilai ragam genetik ditentukan menggunakan rumus heterosigositas individual (h) dan rataan heterosigositas $(\bar{H})$. Hubungan dan jarak genetik antar bangsa kelinci menggunakan program DISPAN dan MEGA 6.06. Analisis statistika menggunakan tabel $X^{2}$ untuk menguji lokus-lokus dalam keseimbangan Hukum Hardy-Weinberg (HHW). Hasil penelitian menunjukkan bahwa lokus pre-albumin $(P a)$, albumin $(A l b)$, ceruloplasmin $(C p)$, transferin $(T f)$, post-transferin $(P-t f)$ dan amylase-I $(A m-I)$ pada Kelinci rex, lokal dan NZW bersifat polimorfik. Kelinci rex dan NZW memiliki hubungan genetik yang dekat berdasarkan analisis pohon filogeni. Hasil uji $X^{2}$ pada kelinci rex, lokal dan NZW menunjukkan keseimbangan HHW pada lokus $P a$, dan $C p$, sedangkan pada lokus Alb, Tf, P-tf dan Amy-I memiliki keseimbangan HW yang berbeda-beda. Simpulan dari penelitian ini adalah terdapat keragaman genetik enam lokus pada kelinci rex, local, dan NZW.
\end{abstract}

Kata-kata kunci: kelinci; rex; lokal; NZW; polimorfisme; keragaman genetik.

\begin{abstract}
The objective of this study was to determine genetic diversity of rabbit by blood plasma protein variance using electrophoresis at loci of pre-albumin $(P a)$, albumin $(A l b)$, ceruloplasmin $(C p)$, transferrin $(T f)$, post-transferrin $(P-t f)$ and amylase-I $(A m-I)$. The blood analysis was performed at the Laboratory of Physiology and Biochemistry, Faculty of Veterinary Medicine, Gadjah Mada University, Yogyakarta. The materials used were 63 blood samples of rex, local and new zealand white (NZW) rabbit, in which the number of sample in each breed was 21, respectively. Materials were taken randomly. The protein bands resulted from electrophoresis were used to calculate the value of the gene frequenc. $\mathrm{v}$. Genetic diversity was determined by using individual heterozygosity $(\mathrm{h})$ and the average heterozygosity $(\bar{H})$ formulas. The genetic distance among breeds of rabbits was analyzed by using DISPAN and MEGA 6.06 programs. Chi-square $\left(X^{2}\right)$ was used to test of Hardy-Weinberg Law (HWL) equilibrium. The results showed that the loci of prealbumin $(P a)$, albumin $(A l b)$, ceruloplasmin $(C p)$, transferrin $(T f)$, post-transferrin $(P$ - $t f)$ and amylase-I $(A m-I)$ in Rex, local and NZW rabbits were polymorphic. Rex and NZW rabbits had close genetic relationships based on phylogeny tree analysis. Chi-square test showed that rex, local and NZW rabbits were in HWL equilibrium for locus of $P a$, and $C p$, while at the locus of $A l b, T f$, P-tf and $A m y-I$ were in HWL unequilibrium. In conclusion, there are genetic variability of six locuses in rex, local and NZW rabbits.
\end{abstract}

Key words: rabbit; rex; local; NZW; polymorphism; genetic diversity 


\section{PENDAHULUAN}

Kelinci (Oryctolagus cuniculus) merupakan ternak herbivora yang dalam sistematik zoologis diklasifikasikan dalam filum Chordata, kelas Mammalia, orda Logomorpha, family Leporidae, genus Orcytolagus dan spesies Orcytolagus cuniculus (Lebas et al., 1997). Kelinci yang banyak dibudidayakan di Indonesia merupakan jenis kelinci impor dari berbagai negara di Eropa dan Amerika. Di bidang perternakan, peternakan kelinci merupakan kegiatan industri yang sampai saat ini berjalan secara komersil untuk diambil daging dan kulit. Selain itu kelinci digunakan sebagai kepentingan penelitian di laboratorium. Kelinci yang banyak ditemukan pada peternakan rakyat sekarang ini berasal dari kelinci liar. Namun, karena sudah dilakukan perkawinan silang antara bangsa kelinci lokal dan kelinci impor, serta sudah dilakukan penjinakan, maka kelinci dipelihara sebagai penghasil daging untuk kebutuhan konsumsi manusia. Dinyatakan oleh Brahmantiyo dan Raharjo (2009) bahwa produktivitas karkas kelinci yang tinggi membuat bangsa kelinci rex mulai diternakan untuk diambil dagingnya. Kelinci rex selain dikenal sebagai penghasil daging, juga dikenal sebagai penghasil rambut yang halus dan kilap dengan produktivitas rambut dan daging yang cukup tinggi.

Penampilan seekor ternak merupakan hasil dari pengaruh genetik dan lingkungan serta mungkin interaksi keduanya. Pada suatu populasi yang lingkungannya relatif sama, keragaman fenotipik merupakan ekspresi keragaman genetiknya. Polimorfieme merupakan gambaran keragaman genetik pada lokus-lokus yang mengekspresikan sifat-sifat tertentu. Polimorfisme pada ternak, termasuk kelinci, diperlukan untuk mengetahui tingkat keragaman genetik yang dapat digunakan sebagai penanda molekuler. Jenis protein dalam darah dapat menunjukkan polimorfisme dengan menggunakan prosedur elektroforesis yang merupakan cerminan adanya perbedaan genetik. Alel dengan bobot molekul berbeda akan menunjukkan mobilitas yang berbeda dari katoda ke anoda pada proses elektroforesis dan menghasilkan gambaran genotip yang berbeda (Astuti, 1997). Polyacrylamid Gel Electrophoresis sebagai salah satu metode elektroforesis sering digunakan untuk memisahkan protein berdasarkan perbedaan migrasi atau pergerakan pada sebuah medan listrik. Dinyatakan oleh Brata et al. (2013), perbedaan kecepatan gerak dari masing-masing protein dipengaruhi oleh bobot molekul protein tersebut.

Parameter yang dapat digunakan untuk mengukur keragaman genetik adalah dengan rataan heterozigositas per lokus. Laju peningkatan heterozigositas pada komoditas ternak tergantung pada pola perkawinan dan proses seleksi yang terjadi. Menurut Maeda et al. (1992), silang luar antar tetua yang berbeda genetiknya merupakan salah satu penyebab terjadinya heterosigositas. Informasi mengenai analisis molekuler genetik melalui frekuensi gen dan heterosigositas pada kelinci masih terbatas. Oleh karena itu penelitian tentang analisis keragaman genetik pada kelinci menjadi penting.

Tujuan penelitian ini adalah untuk mengetahui keragaman genetik kelinci rex, lokal dan NZW melalui analisis protein darah prealbumin $(P a)$, albumin $(A l b)$, ceruloplasmin $(C p)$, transferin $(T f)$, post-transferin $(P t f)$, dan amylase-I (Am-I).

\section{METODE PENELITIAN}

Pada penelitian ini, materi yang digunakan adalah 63 sampel darah kelinci Rex, Lokal, dan New Zealand White masing-masing sebanyak 21 sampel plasma darah yang diambil secara acak dari Kabupaten Temanggung dan Purworejo, Provinsi Jawa Tengah, dan dari Kabupaten Kulon Progo dan Bantul, Provinsi Daerah Istimewa Yogyakarta.

\section{Analisis Sampel}

Pengambilan sampel darah dilakukan pada vena auricularis menggunakan spoit ukuran 23 gauge/G. Darah dikumpulkan dalam tabung yang berisi antikoagulan EDTA. Darah dipusing selama empat menit dengan kecepatan $3500 \mathrm{rpm}$ untuk memisahkan plasma darah dari sel darah merah. Plasma darah yang terpisah diambil dengan pipet, lalu dimasukan ke dalam minitube berlabel dan disimpan dalam lemari pembeku (freezer) $-20^{\circ} \mathrm{C}$ hingga proses analisis.

Analisis Poliakrilamida Gel Electrophoresis (PAGE) dengan metode Ogita dan Markert (1979). Pita-pita yang dihasilkan dari proses elektroforesis digunakan untuk melakukan interpretasi alel pada lokus pre-albumin $(P a)$, albumin $(A l b)$, ceruloplasmin $(C p)$, transferin $(T f)$, post-transferin $(P t f)$ dan amylase$\mathrm{I}(A m-I)$. 


\section{Analisis Data}

Gerakan alel setiap lokus diamati untuk menghitung frekuensi alel, dianalisis berdasarkan rumus Warwick et al. (1995) sebagai berikut :

$\mathrm{F}_{\mathrm{Ai}}=\frac{\sum \text { Aldi } A_{1}}{\sum \text { alel } A_{\mathrm{L}}+\ldots \ldots .+\sum \text { alel } A_{3}}$

dalam hal ini $\mathrm{F}_{\mathrm{Ai}}=$ frekuensi alel A pada lokus ke-i, " alel A • = total alel ke-1 pada lokus ke-n, dan "alel $\mathrm{A}_{3}$ = total alel ke-3 pada lokus ke-n.

Keragaman genetik kelinci dihitung menggunakan rumus heterosigositas individual (h) berdasarkan rumus dari Nei (1973) dan rataan heterosigositas () berdasarkan rumus dari Nozawa et al. (1978) sebagai berikut :

$\mathrm{h}=1-\sum q^{2}$

$\vec{H}=\frac{\sum h}{r}$

dalam hal ini $\mathrm{h}=$ heterosigositas individual, $\mathrm{r}=$ jumlah lokus yang diamati, $q i=$ frekuensi gen ke- $\mathrm{I}$, dan = rataan heterosigositas.

Nilai harapan genotip keseimbangan Hukum Hardy-Weinberg dianalisis berdasarkan rumus Bruce (1981) sebagai berikut:

Nilai harapan genotip dua alel $=\mathrm{p}^{2}(\mathrm{n})+$ $2 p q(n)+q^{2}(n)$; Nilai harapan genotip tiga alel $=\mathrm{p}^{2}(\mathrm{n})+2 \mathrm{pq}(\mathrm{n})+2 \mathrm{pr}(\mathrm{n})+\mathrm{q}^{2}(\mathrm{n})+2 \mathrm{qr}(\mathrm{n})+\mathrm{r}^{2}(\mathrm{n})$. Dalam hal ini $\mathrm{n}=$ total sampel, $\mathrm{p}=$ frekuensi gen alel ke-1, q = frekuensi gen alel ke-2, dan r $=$ frekuensi gen alel ke-3

Jarak genetik diperkirakan berdasarkan pohon filogenetik (Nei dan Kumar, 2000). Pohon filogenetik tiga bangsa kelinci ditampilkan dalam program DISPAN dan MEGA 6.06. Uji $X^{2}$ digunakan untuk menguji perhitungan keseimbangan tiap lokus berdasarkan Hukum Hardy Weinberg (Bruce, 1981) :

$X^{2}=\sum \frac{(O-H)^{2}}{H}$

Dalam hal ini: $X^{2}=$ Chi square hitung, $O=$ Nilai genotipe yang diperoleh dari pengamatan, dan $H=$ Nilai harapan menurut keseimbangan Hukum Hardy Weinberg

\section{HASIL DAN PEMBAHASAN}

Salah satu hasil analisis elektroforesis protein plasma darah bangsa kelinci rex, lokal, dan NZW pada protein darah pre-albumin, albumin, ceruloplasmin, transferin, posttransferin, dan amylase-I disajikan pada Gambar 1. Pita-pita yang muncul merupakan gambaran pergerakan protein-protein, yang dalam hal ini adalah lokus-lokus pada sampel darah. Perbedaan kecepatan gerak dari masingmasing lokus dipengaruhi oleh bobot molekul dari protein (Brata et al., 2013).

\section{Pre-albumin}

Lokus pre-albumin pada tiga bangsa kelinci dikontrol oleh tiga jenis alel yaitu alel $P a^{1}, P a^{2}$, dan alel $P a^{3}$. Alel $P a^{1}$ bergerak lebih cepat ke kutub positif diikuti alel $P a^{2}$ dengan gerakan sedang, dan alel $P a^{3}$ bergerak lambat. Kristjansson (1963) melaporkan bahwa pada babi ada dua alel yang mengontrol lokus pre-albumin yaitu $P a^{1}$ dan $P a^{2}$. Sementara itu Noviani et al. (2013) pada domba batur melaporkan bahwa frekuensi alel $P a^{2}(0,650)$ lebih tinggi dari frekuensi alel $P a^{1}(0,350)$. Nozawa et al. (1999) melaporkan hasil penelitiannya pada kambing vietnam menunjukkan frekuensi alel $P a^{2}$ $(0,6627)$ lebih tinggi dari $P a^{1}(0,3373)$.

Hasil perhitungan frekuensi alel, nilai harapan genotip dan $X^{2}$ lokus pre-albumin pada kelinci rex, lokal, dan NZW disajikan pada Tabel 1. Hasil penelitian menunjukkan bahwa frekuensi alel $P a^{3}$ lokus pre-albumin pada kelinci lokal, rex dan NZW relatif lebih tinggi masingmasing 0,$619 ; 0,477$; dan 0,333 , sedangkan frekuensi alel $P a^{2}$ lokus pre-albumin pada kelinci NZW, lokal, dan rex masing-masing 0,428; 0,310; dan 0,380. Frekuensi alel $P a^{1}$ lokus prealbumin pada kelinci NZW, rex, dan lokal masing-masing 0,$239 ; 0,143$; dan 0,071. Hasil uji $X^{2}$ menunjukkan bahwa lokus pre-albumin pada kelinci rex, lokal dan NZW $(1,39 ; 2,15$; 10,56) berada dalam keseimbangan Hukum Hardy Weinberg $(p \leq 0,05)$.

\section{Albumin}

Lokus albumin memiliki bobot molekul sebesar $69 \mathrm{kDa}$ (Smithies, 1955). Harper et al. (1980) mengemukakan bahwa molekul albumin 


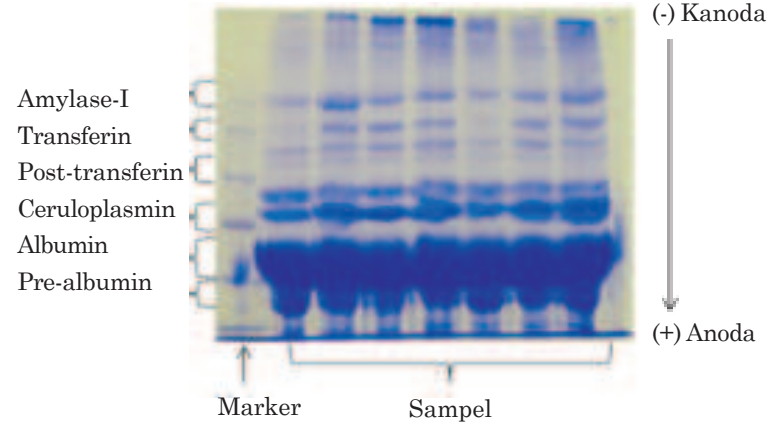

Gambar 1. Hasil elektroforesis yang menunjukkan protein dengan bobot molekul lebih ringan bergerak lebih cepat menuju kutub postif (+).

yang lebih kecil dan memiliki muatan yang lebih besar menunjukkan laju migrasi tercepat, sehingga tampak lebih tebal. Pada tiga bangsa kelinci, lokus albumin dikontrol oleh dua sebaran alel yaitu $A l b^{B}$ dan $A l b^{C}$. Alel $A l b^{B}$ bergerak lebih cepat ke kutub positif dan $A l b^{C}$ bergerak lambat. Ferrand dan Rocha (1992) menunjukkan dua alel yang mengontrol lokus albumin pada kelinci england yaitu alel $A l b^{B}$ dan $A l b^{C}$. Frekuensi alel $A l b^{B}$ kelinci england lebih tinggi $(0,60)$ dibandingkan alel $A l b^{C}(0,40)$. Hasil penelitian Tsunoda et al. (1998) pada domba mongolia frekuensi alel $A l b^{C}$ relatif lebih tinggi yaitu $(0,9897)$ dibandingkan alel $A l b^{B}(0,0103)$.

Hasil perhitungan frekuensi alel, nilai harapan genotip, dan $X^{2}$ lokus albumin pada kelinci rex, lokal dan NZW disajikan pada Tabel 2. Hasil penelitian menunjukkan bahwa frekuensi alel $A l b^{B}$ pada tiga bangsa kelinci relatif lebih tinggi masing-masing 0,$690 ; 0,761$; dan 0,523 dari pada frekuensi alel $A l b^{C}$ masingmasing 0,310; 0,239; dan 0,477. Hasil uji $X^{2}$ menunjukkan bahwa lokus albumin pada kelinci NZW $(0,44)$ berada dalam keseimbangan Hukum Hardy Weinberg $(p \leq 0,05)$.

\section{Ceruloplasmin}

Ceruloplasmin pada kelinci rex, lokal, dan NZW dikontrol oleh dua alel yaitu $C p^{A}$ dan $C p^{B}$. Alel $C p^{A}$ bergerak lebih cepat ke kutub positif diikuti alel $C p^{B}$ dengan gerakan lambat. Hasil penelitian Juneja et al. (1984) menunjukkan bahwa pada kuda lokus ceruloplasmin dikendalikan oleh dua alel yaitu $C p^{A}$ dan $C p^{B}$.

Hasil perhitungan frekuensi alel, nilai harapan genotip, dan $X^{2}$ lokus ceruloplasmin pada kelinci rex, lokal, dan NZW disajikan pada Tabel 3. Hasil penelitian menunjukkan bahwa frekuensi alel $C p^{B}$ pada kelinci rex, lokal dan NZW relatif lebih tinggi masing-masing 0,690 ; 0,547; dan 0,667 dibandingkan frekuensi alel $C p^{A}$ masing-masing 0,$310 ; 0,453$; dan 0,333 . Hasil uji $X^{2}$ menunjukkan bahwa lokus ceruloplasmin pada kelinci rex, lokal dan NZW $(9,28 ; 2,24 ; 2,67)$ berada dalam keseimbangan Hukum Hardy Weinberg $(p \leq 0,05)$.

\section{Transferin}

Lokus transferin memiliki bobot molekul sebesar $75 \mathrm{kDa}$ (Morgan, 1969). Lokus transferin pada tiga bangsa kelinci dikontrol oleh dua alel yaitu alel $T f^{A}$ dan alel $T f^{B}$. Alel $T f^{A}$ bergerak lebih cepat menuju kutub positif diikuti alel $T f^{B}$ bergerak lambat. Ferrand et al. (1988) melaporkan bahwa pada kelinci liar ditemukan dua alel yang mengontrol lokus transferin yaitu alel $T f^{A}$ dan $T f^{B}$. Alel $T f^{A}$ bergerak lebih cepat ke kutub positif dan alel $T f^{B}$ gerakan lambat, dengan frekuensi gen alel $T f^{B}(0,05)$ lebih tinggi dan frekuensi gen alel $T f^{A}$ yang rendah $(0,03)$.

Tabel 1. Perhitungan frekuensi alel, nilai harapan genotip dan $X^{2}$ lokus pre-albumin pada kelinci rex, lokal dan New Zealand White

\begin{tabular}{|c|c|c|c|c|c|c|c|c|c|c|c|}
\hline \multirow{2}{*}{ Bangsa } & \multirow{2}{*}{ Angka } & \multicolumn{6}{|c|}{ Genotip } & \multicolumn{3}{|c|}{ Frekuensi alel } & \multirow{2}{*}{$X^{2}$} \\
\hline & & $P a^{1-1}$ & $P a^{1-2}$ & $P a^{1-3}$ & $P a^{2-2}$ & $P a^{2-3}$ & $P a^{3-3}$ & $P a^{1}$ & $P a^{2}$ & $P a^{3}$ & \\
\hline \multirow[t]{2}{*}{ Rex } & $O$ & 0 & 2 & 4 & 3 & 8 & 4 & 0,143 & 0,380 & 0,477 & $1,39^{\mathrm{s}}$ \\
\hline & $H$ & 0,430 & 2,282 & 2,865 & 3,032 & 7,612 & 4,779 & & & & \\
\hline \multirow[t]{2}{*}{ Lokal } & $O$ & 0 & 0 & 3 & 2 & 9 & 7 & 0,071 & 0,310 & 0,619 & $2,15^{\mathrm{s}}$ \\
\hline & $H$ & 1,106 & 0,924 & 1,846 & 2,018 & 8,059 & 8,047 & & & & \\
\hline \multirow[t]{2}{*}{ NZW } & $O$ & 3 & 0 & 4 & 7 & 4 & 3 & 0,239 & 0,428 & 0,333 & $10,56^{\mathrm{s}}$ \\
\hline & $H$ & 1,106 & 0,924 & 1,846 & 2,018 & 8,059 & 8,047 & & & & \\
\hline
\end{tabular}

Keterangan: $X^{2}$ (tabel 0,05 = 11,07), $X^{2} \leq 0,05=$ signifikan, $X^{2} \geq 0,05=$ non signifikan, $O=$ Observasi, $H=$ Harapan, $\mathrm{N}=\sum$ sampel $=21, \mathrm{NZW}=$ New Zealand White 
Hasil perhitungan frekuensi alel, nilai harapan genotip, dan $X^{2}$ lokus transferin pada kelinci rex, lokal dan NZW disajikan pada Tabel 4. Hasil penelitian menunjukkan bahwa frekuensi alel $T f^{B}$ pada kelinci rex, lokal, dan NZW relatif lebih tinggi masing-masing 0,667 ; 0,596; dan 0,714, sedangkan frekuensi alel $T f^{A}$ masing-masing 0,$333 ; 0,404$; dan 0,286. Hasil uji $X^{2}$ menunjukkan bahwa lokus transferin pada kelinci rex, lokal dan NZW tidak berada dalam keseimbangan Hukum Hardy Weinberg $(\mathrm{p} \geq 0,05)$.

\section{Post-transferin}

Lokus post-transferin pada bangsa kelinci rex, lokal, dan NZW dikontrol oleh dua alel yaitu alel $P$ - $t f^{f}$ dan alel $P$-tf ${ }^{S}$. Alel $P$ - $t f^{f}$ bergerak lebih cepat ke kutub positif diikuti alel $P$-tf ${ }^{S}$ bergerak lambat. Takaendengan et al. (2011) menunjukkan bahwa pada kuda lokus posttransferin terdiri dari dua alel yaitu alel $P$-tf $f$ dan alel $P-t f S$. Sementara itu Dewanti et al. (2013) menunjukkan bahwa pada kambing kejobong frekuensi alel lebih tinggi pada alel $P$ $t f^{S}(0,813)$ dibandingkan alel $P$ - $t f^{f}(0,187)$.

Hasil perhitungan frekuensi alel, nilai harapan genotip, dan $X^{2}$ lokus post-transferin pada kelinci rex, lokal, dan NZW disajikan pada Tabel 5. Hasil penelitian menunjukkan bahwa frekuensi alel $P$ - $t f^{S}$ pada kelinci rex, lokal, dan NZW relatif lebih tinggi masing-masing 0,738 ; 0,500; dan 0,642 daripada frekuensi alel P-tf $F^{F}$ masing-masing 0,262; 0,500 dan 0,358. Hasil uji $X^{2}$ menunjukkan bahwa lokus post-transferin pada kelinci rex dan lokal $(0,39$ dan 5,76$)$ berada dalam keseimbangan Hukum Hardy Weinberg $(p \leq 0,05)$.

Tabel 2. Perhitungan frekuensi alel, nilai harapan genotip dan $X^{2}$ lokus albumin pada kelinci rex, lokal dan New Zealand White

\begin{tabular}{|c|c|c|c|c|c|c|c|}
\hline \multirow{2}{*}{ Bangsa } & \multirow{2}{*}{ Angka } & \multicolumn{3}{|c|}{ Genotip } & \multicolumn{2}{|c|}{ Frekuensi alel } & \multirow{2}{*}{$X^{2}$} \\
\hline & & $A l b^{B-B}$ & $A l b^{B-C}$ & $A l b^{C-C}$ & $A l b^{B}$ & $A l b^{C}$ & \\
\hline \multirow[t]{2}{*}{ Rex } & $O$ & 8 & 13 & 0 & \multirow[t]{2}{*}{0,690} & \multirow[t]{2}{*}{0,310} & \multirow[t]{2}{*}{$68,84^{\mathrm{ns}}$} \\
\hline & $H$ & 9,999 & 8,983 & 2,018 & & & \\
\hline \multirow[t]{2}{*}{ Lokal } & $O$ & 15 & 2 & 4 & \multirow[t]{2}{*}{0,761} & \multirow[t]{2}{*}{0,239} & \multirow[t]{2}{*}{$11,36^{\mathrm{ns}}$} \\
\hline & $H$ & 12,162 & 7,639 & 1,199 & & & \\
\hline \multirow[t]{2}{*}{ NZW } & $O$ & 5 & 12 & 4 & \multirow[t]{2}{*}{0,523} & \multirow[t]{2}{*}{0,477} & \multirow[t]{2}{*}{$0,44^{\mathrm{s}}$} \\
\hline & $H$ & 5,745 & 10,477 & 4,778 & & & \\
\hline
\end{tabular}

Keterangan: $X^{2}$ (tabel 0,05 =11,07), $X^{2} \leq 0,05=$ signifikan, $X^{2} \geq 0,05=$ non signifikan, $O=$ Observasi, $H=$ Harapan, $\mathrm{N}=\sum$ sampel $=21, \mathrm{NZW}=$ New Zealand White

Tabel 3. Perhitungan frekuensi alel, nilai harapan genotip dan $X^{2}$ lokus ceruloplasmin pada kelinci rex, lokal dan New Zealand White

\begin{tabular}{|c|c|c|c|c|c|c|c|}
\hline \multirow{2}{*}{ Bangsa } & \multirow{2}{*}{ Angka } & \multicolumn{3}{|c|}{ Genotip } & \multicolumn{2}{|c|}{ Frekuensi alel } & \multirow{2}{*}{$X^{2}$} \\
\hline & & $C p^{A-A}$ & $C p^{A \cdot B}$ & $C p^{B-B}$ & $C p^{A}$ & $C p^{B}$ & \\
\hline \multirow[t]{2}{*}{ Rex } & $O$ & 5 & 3 & 13 & 0,310 & 0,690 & $9,28^{\mathrm{s}}$ \\
\hline & $H$ & 2,018 & 8,983 & 9,999 & & & \\
\hline \multirow[t]{2}{*}{ Lokal } & $O$ & 6 & 7 & 8 & 0,453 & 0,547 & $2,24^{\mathrm{s}}$ \\
\hline & $H$ & 2,018 & 8,983 & 9,999 & & & \\
\hline \multirow[t]{2}{*}{ NZW } & $O$ & 4 & 6 & 11 & 0,333 & 0,667 & $2,67^{\mathrm{s}}$ \\
\hline & $H$ & 2,329 & 9,329 & 9,342 & & & \\
\hline
\end{tabular}

Keterangan: $X^{2}($ tabel $0,05=11,07), X^{2} \leq 0,05=$ signifikan, $X^{2} \leq 0,05=$ non signifikan, $O=$ Observasi, $H=$ Harapan, $\mathrm{N}=\sum$ sampel $=21, \mathrm{NZW}=$ New Zealand White 
Tabel 4. Perhitungan frekuensi alel, nilai harapan genotip dan $X^{2}$ lokus transferin pada kelinci rex, lokal dan New Zealand White

\begin{tabular}{lccccccc}
\hline & & \multicolumn{5}{c}{ Genotip } & \multicolumn{3}{c}{ Frekuensi alel } & \multirow{2}{*}{$X^{2}$} \\
\cline { 3 - 6 } Bangsa & Angka & $T f^{A \cdot A}$ & $T f^{A \cdot B}$ & $T f^{B-B}$ & $T f^{A}$ & $T f^{B}$ & \\
\hline Rex & $O$ & 7 & 0 & 14 & 0,333 & 0,667 & \multirow{2}{*}{$21,01^{\text {ns }}$} \\
& $H$ & 2,330 & 9,326 & 9,344 & & & \\
Lokal & $O$ & 8 & 1 & 12 & 0,404 & 0,596 & \multirow{2}{*}{$17,07^{\mathrm{ns}}$} \\
& $H$ & 23,428 & 10,113 & 7,459 & & & \\
NZW & $O$ & 6 & 0 & 15 & 0,286 & 0,714 & $20,97^{\mathrm{ns}}$ \\
& $H$ & 1,718 & 8,576 & 10,706 & & & \\
\hline
\end{tabular}

Keterangan: $X^{2}$ (tabel 0,05 =11,07), $X^{2} \leq 0,05=$ signifikan, $X^{2} \leq 0,05=$ non signifikan, $O=$ Observasi, $H=$ Harapan, $\mathrm{N}=\sum$ sampel $=21, \mathrm{NZW}=$ New Zealand White

Tabel 5. Perhitungan frekuensi alel, nilai harapan genotip dan $X^{2}$ lokus post-transferin pada kelinci rex, lokal dan New Zealand White

\begin{tabular}{|c|c|c|c|c|c|c|c|}
\hline \multirow{2}{*}{ Bangsa } & \multirow{2}{*}{ Angka } & \multicolumn{3}{|c|}{ Genotip } & \multicolumn{2}{|c|}{ Frekuensi alel } & \multirow{2}{*}{$X^{2}$} \\
\hline & & $P-t f^{F-F}$ & $P-t f^{F-S}$ & $P-t f^{S-S}$ & $P-t f^{F}$ & $P-t f^{S}$ & \\
\hline \multirow[t]{2}{*}{$\operatorname{Rex}$} & $O$ & 2 & 7 & 12 & 0,262 & 0,738 & $0,39^{\mathrm{s}}$ \\
\hline & $H$ & 1,442 & 8,120 & 11,438 & & & \\
\hline \multirow[t]{2}{*}{ Lokal } & $O$ & 8 & 5 & 8 & 0,500 & 0,500 & $5,76^{\mathrm{s}}$ \\
\hline & $H$ & 1,442 & 8,120 & 11,438 & & & \\
\hline \multirow[t]{2}{*}{ NZW } & $O$ & 7 & 1 & 13 & 0,358 & 0,642 & $17,20^{\text {ns }}$ \\
\hline & $H$ & 2,692 & 9,653 & 8,655 & & & \\
\hline
\end{tabular}

Keterangan: $X^{2}$ (tabel 0,05 =11,07), $X^{2} \leq 0,05=$ signifikan, $X^{2} \leq 0,05=$ non signifikan, $O=$ Observasi, $H=$ Harapan, $\mathrm{N}=\sum$ sampel $=21, \mathrm{NZW}=$ New Zealand White

Tabel 6. Perhitungan frekuensi alel, nilai harapan genotip dan $X^{2}$ lokus amylase-I pada kelinci rex, lokal dan New Zealand

\begin{tabular}{|c|c|c|c|c|c|c|c|c|c|c|c|}
\hline \multirow{2}{*}{ Bangsa } & \multirow{2}{*}{ Angka } & \multicolumn{6}{|c|}{ Genotip } & \multicolumn{3}{|c|}{ Frekuensi alel } & \multirow{2}{*}{$X^{2}$} \\
\hline & & $A m^{1-1}$ & $A m^{1-2}$ & $A m^{1-3}$ & $A m^{2-2}$ & $A m^{2-3}$ & $A m^{3-3}$ & $A m^{1}$ & $A m^{2}$ & $A m^{3}$ & \\
\hline \multirow[t]{2}{*}{$\operatorname{Rex}$} & $O$ & 0 & 3 & 1 & 6 & 2 & 9 & 0,095 & 0,405 & 0,500 & $11,42^{\mathrm{ns}}$ \\
\hline & $H$ & 0,189 & 1,616 & 1,996 & 3,444 & 8,505 & 5,250 & & & & \\
\hline \multirow[t]{2}{*}{ Lokal } & $O$ & 4 & 1 & 0 & 7 & 0 & 9 & 0,214 & 0,358 & 0,428 & $35,20^{\mathrm{ns}}$ \\
\hline & $H$ & 0,962 & 3,218 & 3,847 & 2,691 & 6,435 & 3,847 & & & & \\
\hline \multirow[t]{2}{*}{ NZW } & $O$ & 8 & 2 & 1 & 3 & 0 & 7 & 0,452 & 0,190 & 0,358 & $25,21^{\mathrm{ns}}$ \\
\hline & $H$ & 4,290 & 3,607 & 6,797 & 0,758 & 2,856 & 2,692 & & & & \\
\hline
\end{tabular}

Keterangan: $X^{2}$ (tabel 0,05 = 11,07), $X^{2} \leq 0,05=$ signifikan, $X^{2} \leq 0,05=$ non signifikan, $O=$ Observasi, $H=$ Harapan, $\mathrm{N}=\sum$ sampel $=21, \mathrm{NZW}=$ New Zealand White 
Tabel 7. Rataan heterosigositas (H) protein plasma darah kelinci rex, lokal, dan New Zealand White/NZW

\begin{tabular}{ccccccccc}
\hline \multirow{2}{*}{ Bangsa } & \multicolumn{7}{c}{$\mathrm{H}$} & \multirow{2}{*}{$\mathrm{H}$} \\
\cline { 2 - 7 } & $\mathrm{Pa}$ & $\mathrm{Alb}$ & $\mathrm{Cp}$ & $\mathrm{Tf}$ & $\mathrm{P}$-tf & Am-I & \\
\hline Rex & 0,607 & 0,427 & 0,427 & 0,444 & 0,386 & 0,576 & 0,477 \\
Lokal & 0,515 & 0,363 & 0,465 & 0,481 & 0,500 & 0,642 & 0,494 \\
NZW & 0,648 & 0,498 & 0,444 & 0,408 & 0,459 & 0,631 & 0,514 \\
\hline
\end{tabular}

Keterangan: $\mathrm{Pa}=$ pre-albumin, alb $=$ albumin, $\mathrm{Cp}=$ ceruloplasmin, $\mathrm{Tf}=$ transferin, $\mathrm{P}$-tf $=$ post-ransferin, Am-I = amylase-I, $\mathrm{h}=$ heterosigositas individual, dan $\bar{H}=$ rataan heterosigositas

\section{Amylase-I}

Lokus amylase-I pada kelinci rex, lokal, dan NZW dikontrol oleh tiga jenis alel yaitu alel $\mathrm{Am}$ $I^{1}$, alel $A m y-I^{2}$, dan alele $A m y-I^{3}$. Noviani et al. (2013) melaporkan bahwa pada tiga bangsa domba ditemukan dua sebaran alel yang mengontrol lokus amylase-I yaitu $A m y-I^{2}$ dan Amy-I $I^{3}$, sedangkan Khana (1973) menemukan dua sebaran alel lokus amylase-I pada keledai yaitu alel $A m-I^{B}$ dan $A m-I^{C}$. Sementara itu Mazumder dan Spooner (1970) memperlihatkan frekuensi alel $A m-I^{2}$ pada sapi friesian dan sapi ayrshire lebih tinggi masing-masing 0,5171 dan 0,6638 dibandingkan dengan alel $A m-I^{1}$ yang rendah masing-masing 0,4829 dan 0,3362.

Hasil perhitungan frekuensi alel, nilai harapan genotip, dan $X^{2}$ lokus amylase-I pada kelinci rex, lokal dan NZW disajikan pada Tabel 6. Hasil penelitian menunjukkan bahwa frekuensi alel $A m-I^{3}$ pada kelinci rex, lokal, dan NZW relatif lebih tinggi masing-masing 0,500; 0,428; dan 0,358, frekuensi alel $A m-I^{2}$ masingmasing 0,405; 0,358 dan 0,190, dan frekuensi alel $A m-I^{1}$ masing-masing 0,095; 0,214 dan 0,452. Hasil uji $X^{2}$ menunjukkan bahwa lokus amylase-I pada kelinci rex, lokal dan NZW tidak berada dalam keseimbangan Hukum Hardy Weinberg $(p \leq 0,05)$.

\section{Analisis Heterosigositas Individu dan Rataan Heterosigositas}

Nilai heterosigositas individu (h) dan rataan heterosigositas $(\bar{H})$ protein darah kelinci lokal, rex, dan NZW disajikan pada Tabel 7. Tabel 7 memperlihatkan bahwa heterosigositas lokus $P a$ dan Alb pada kelinci NZW lebih tinggi daripada kelinci rex dan lokal, sedangkan pada lokus ceruloplasmin, transferin, post-transferin, dan amylase-I pada kelinci lokal yang tinggi. Rataan heterosigositas menunjukkan bahwa kelinci NZW lebih tinggi $(0,552)$ dari kelinci rex dan lokal (0,478 dan 0,494). Erina dan Ediyanto (2012) melaporkan bahwa heterosigositas lokus transferin pada domba lebih tinggi yaitu 0,455 daripada lokus albumin dan post-albumin yaitu masing-masing 0,48 dan 0,50. Tingginya rataan heterosigositas menunjukkan bahwa tingkat keragaman genetik setiap lokus pada kelinci NZW tinggi. Faktor yang memengaruhi tingginya heterosigositas pada kelinci NZW mungkin karena lokasi pengambilan sampel yang dilakukan. Seleksi yang berbeda dalam populasi yang berbeda bertanggungjawab dalam mempertahankan tingkat keragaman setiap lokus (Gilliespie, 1991). Kelinci NZW yang diambil dari tiga lokasi yang berbeda, yaitu Kabupaten Temanggung, Kulon Progo, dan Bantul menyebabkan tingkat keragaman gen lebih tinggi dibandingkan kelinci rex dan lokal yang hanya diambil dari satu lokasi yang sama. Keragaman genetik yang tinggi mengindikasikan potensi pewarisan gen yang relatif lebih tinggi pada gen yang berasal dari setiap lokus protein (Ismoyowati, 2008).

\section{Analisis Jarak Genetik}

Hasil matriks jarak genetik bangsa kelinci rex, lokal, dan NZW disajikan pada Tabel 8. Dari hasil nilai matriks jarak genetik tiap bangsa kelinci yang disajikan dalam Tabel 8

Tabel 8. Matriks jarak genetik bangsa kelinci rex, lokal, dan New Zealand White/ NZW

\begin{tabular}{lrrr}
\hline Bangsa & $\begin{array}{r}\text { Kelinci } \\
\text { Rex }\end{array}$ & $\begin{array}{r}\text { Kelinci } \\
\text { Lokal }\end{array}$ & $\begin{array}{r}\text { Kelinci } \\
\text { NZW }\end{array}$ \\
\hline Kelinci Rex & 0,0 & & \\
Kelinci Lokal & 0,0117 & 0,0 & \\
Kelinci NZW & 0,0005 & 0,0214 & 0,0 \\
\hline
\end{tabular}




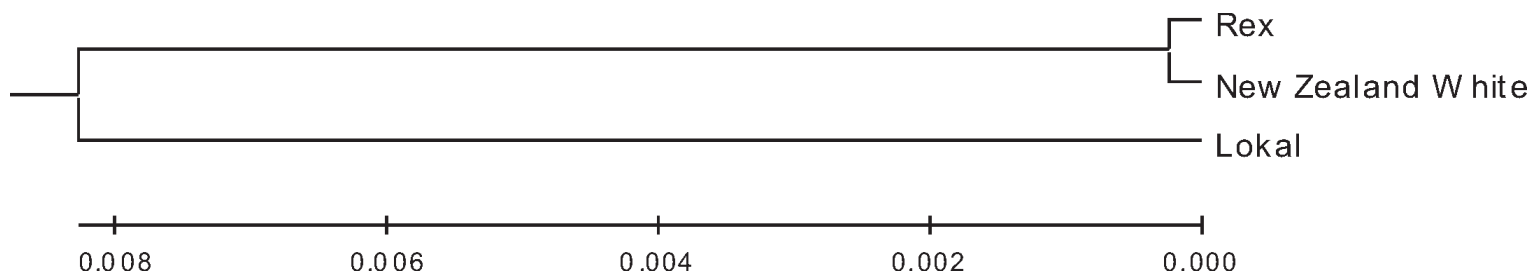

Gambar 2. Pohon filogeni kelinci rex, lokal, dan New Zealand White

digunakan untuk membuat pohon filogeni yang disajikan pada Gambar 2 untuk dapat menggambarkan jarak genetik ketiga bangsa kelinci. Hasil menunjukkan bahwa hubungan genetik yang sangat dekat antara kelinci rex dengan NZW $(0,0005)$ dibandingkan kelinci lokal dan NZW $(0,0214)$ dan antara kelinci rex dengan lokal yang memiliki hubungan genetik yang jauh $(0,0117)$. Dari hasil penelitian Brahmantiyo et al. (2016) didapatkan bahwa kelinci rex dan kelinci satin memiliki jarak genetik yang cukup dekat yaitu sebesar $(0,82)$ ini dimungkinkan karena kedua bangsa kelinci ini merupakan satu rumpun yang sama. Keragaman hubungan genetik ini mungkin disebabkan karena keturunan yang berbeda, kondisi geografis, dan iklim yang berbeda yang menyebabkan variabilitas gen. Kelinci rex dan NZW merupakan bangsa kelinci impor yang dijaga kemurniannya dengan sistem pemeliharaan dan sistem perkawinan yang terseleksi dengan sangat baik, sehingga menunjukkan hubungan kekerabatan yang sangat dekat. Jika dilihat dari frekuensi alel, setiap lokus protein menunjukkan nilai yang relatif sama atau dekat antara kelinci rex dengan kelinci NZW. Hal ini menguatkan pendapat Brahmantiyo et al. (2006) bahwa kelinci yang dikembangkan di masing-masing wilayah akan menampilkan fenotipik yang berbeda yang mengambarkan belum adanya mutasi atau pertukaran ternak. Menurut Nei dan Kumar (2000) bahwa semakin jauh hubungan kekerabatan, mengindikasikan adanya keragaman atau variasi yang tinggi pada lokus-lokus protein darah yang diamati. Kelinci lokal merupakan kelinci yang berasal dari Pulau Jawa dengan sistem perkawinan dan peme-liharaan yang tidak terkontrol menyebabkan analisis filogeni kelinci lokal memiliki hubungan genetik yang sangat jauh dengan kelinci rex dan NZW.

\section{SIMPULAN}

Lokus pre-albumin $(P a)$, albumin $(A l b)$, ceruloplasmin $(C p)$, transferin $(T f)$, post- transferin $(P-t f)$, dan amylase-I $(A m-I)$ pada kelinci rex, lokal, dan kelinci NZW bersifat polimorfik. Rataan heterosigositas kelinci NZW lebih tinggi dari pada kelinci rex dan lokal. Jarak genetik kelinci rex dengan kelinci NZW lebih dekat daripada dengan kelinci lokal. Keragaman genetik pada bangsa kelinci dapat dijadikan dasar untuk proses seleksi.

\section{SARAN}

Untuk analisis polimorfisme protein darah kelinci, sebaiknya analisis dilakukan lebih dari keenam protein yang sudah dianalisis, karena pada saat analisis elektroforesis ternyata pada darah kelinci masih ada jenis protein lain yang muncul.

\section{UCAPAN TERIMA KASIH}

Penulis mengucapkan terimakasih kepada Bapak Asep Setiaji di Temanggung, Bapak Rinto Wibowo dan Bapak Johan di Kulon Progo dan Bapak Azis di Bantul selaku pengelola peternakan kelinci atas ijin penelitian yang telah diberikan.

\section{DAFTAR PUSTAKA}

Astuti M. 1997. Estimasi jarak genetik antar populasi kambing kacang, kambing peranakan etawah dan kambing lokal berdasarkan polimorfisme protein darah. Buletin Peternakan 21(1): 1-9.

Bruce W. 1981. Basic Population Genetics. New York Guildford, Surrey, Columbia University Press. Hlm: 95-121.

Brahmantiyo B, Raharjo YC. 2009. Karakteristik Karkas dan Potongan Komersial Kelinci Rex dan Satin. Balai Penelitian Ternak Bogor: Prosiding Seminar Nasional Teknologi Peternakan dan Veteriner. Hlm:688-692. 
Brahmantiyo B, Raharjo YC. 2011. Peningkatan produktivitas kelinci rex, satin dan persilangannya melalui seleksi. Jurnal Ilmu Ternak dan Veteriner 16(4): 243-252.

Brahmantiyo B, Priyono, Rosartio R. 2016. Pendugaan jarak genetik kelinci (Hyla, hycole, hycolex NZW, rex, dan satin) melalui analisis morfometrik. Jurnal Veteriner 17(2): 226-234.

Brata GD, Sutopo, Kurnianto E. 2013. Keragaman protein plasma darah kambing jawarandu di Kabupaten Pemalang. Animal Agriculture Journal 2(1): 136-142.

Dewanti DR, Kurnianto E, Sotopo. 2013. Keragaman protein plasma darah pada kambing kejobong dan kambing peranakan ettawa. Animal Agriculture Journal 2(1): 269-276.

Erina S, Ediyanto H. 2012. Polimorfisme protein darah domba di Kabupaten Batanghari. Jurnal Ilmiah Ilmu-Ilmu Peternakan 15(1): 25-42.

Ferrand N, Rocha J. 1992. Demonstration of serum slbumin (Alb) polymorphism in wild rabbits, Oryctolagus cuniculus, by means of isoelectric focusing. J Anim Genetics 23: 275-278.

Ferrand N, Carvaldo G, Amorim A. 1988. Transferin (Tf) polymorphism in wild rabbit, Orcytolagus cuniculus. J Anim Genet 19: 295-300.

Gillespie JH. 1991. The Causes of Molecular Evolution. Oxford, Oxford University, New York Press. Hlm: 23-24.

Harper HA, Rodwell VW, Mayes PA. 1980. Biokimia. Lange EGC. Jakarta. (Diterjemahkan oleh M. Muliawan). Hlm: 198-227.

Ismoyowati 2008. Kajian deteksi produksi telur itik tegal melalui polimorfisme protein darah. Anim Prod 10(2): 122-128.

Juneja RK, Andersson L, Sanberg K, Gahne B, Adalsteinsson S, Gunnarsson E. 1984. Twodimensional electrophoresis of hourse serum proteins. genetic polymorphism of ceruloplasmin and two other serum proteins. Animal Blood Groups and Biochem Genet 15: 237-250.

Khana ND. 1973. Blood protein in the donkey. $J$ Anim Genet 80(1): 5-7.
Kristjansson FK. 1963. Genetic control of two pre-albumins in pigs. Can J Genet Cytol. 48(138): 1059-1063.

Lebas F, Coudert P, Rouvier R, De Rochambeau H. 1997. Food and agriculture organization of the united nations. Anim Prod Health Series 21(1): 1-17.

Maeda Y, Yamamoto Y, Nishida T, Hasbiguchi T, Okada J, Rajubhandary HB. 1992. Protein polymorphisms in native and red jungle fowls in Nepal. Anim Sci J 5(4): 747752 .

Mazumder NK, Spooner RL. 1970. Studie on bovine serum amylase; Evidence for two loci. Anim Blood Grps Genet 1: 145-156.

Morgan EH. 1969. Transferrin and albumin distributi on and turnover in the rabbit. $J$ Exp Biol Med Sci 47: 361-366.

Nei M. 1973. Analysis of gene diversity in subdivided populations. Proc Nat Acad Sci USA 70(12): 3321-3323.

Nei, M, Kumar S. 2000. Moleculer Evaluation and Phylogenetic. New York, Oxford University Press Inc. Hlm: 231-262.

Nozawa K, Shinjo A, Shotake T. 1978. Population genetics of farm animals. III. Blood-protein variations in the meat goats in Okinawa Islands of Japan. J Anim Breed Genet 95(1-4): 60-77.

Nozawa K, Kenji T, Yoshizane M, Yuichi T, Tsesrejavyan ZT, Horloojau T, Tsendsuren T. 1999. Gene-constitution of the native goat in Mongolia. J Rep Soc Res Native Livestock 17: 83-94.

Noviani F, Sutopo, Kurnianto E. 2013. Hubungan genetik domba wonosobo (Dombos), domba ekor tipis (DET), dan domba batur (Dombat) melalui analisis polimorfisme protein darah. Jurnal Sains Peternakan 11(1): 1-9.

Ogita Z, Market CL. 1979. A miniture system for electrophoresis on polyacrilamide gels. Analytical Biochemistry 99: 233-241.

Smithies O. 1955. Zone elektrophoresis in starch gels group variation in the serum protein of normal human adult. J Biochem 61: 629641.

Takaendengan BJ, Noor RR, Sumantri C, Adiani S. 2011. Jarak genetik populasi kuda 
lokal sulawesi utara berdasarkan analisis morfologi dan polimorfisme protein darah. Jurnal Ilmiah Sains 11(1): 48-57.

Tsunoda K, Hisota O, Takashi A, Kazuhito K, Takao N, Takahiro Y, Yoshio Y, Vo-tong X, Chau BL. 1998. Morphological and genetic characteristics of sheep raised by the cham tribe in Vietnam. J Rep Soc Res Native Livestock 17: 63-73.
Warwick EJ, Astuti JM, Hardjosoebroto W. 1995. Pemuliaan Ternak. Edisi ke - 5. Yogyakarta, Gadjah Mada University Press. Hlm: 17-43. 